\title{
Effect of Water Content on Productive Parameters of Forage Grasses used for Cadmium Phytoextraction in Two Seasons
}

\author{
Flávio Henrique Silveira Rabêlo, Rodrigo Hideki Mano, Luís Reynaldo Ferracciú Alleoni \\ Luiz de Queiroz College of Agriculture, University of São Paulo \\ Pádua Dias Avenue, 11, Zip Code 13418900, Piracicaba, São Paulo, Brazil \\ flaviohsr.agro@usp.br; rodrigohidekimano@usp.br; alleoni@usp.br
}

\section{Extended Abstract}

Tiller and leaf appearance rates are determinant for forage production and can be influenced by environmental conditions such as temperature, water availability and presence of potentially toxic elements. In recent years, several species of forage grasses has been assayed for cadmium $(\mathrm{Cd})$ phytoextraction, but there are no reports about the season effect combined to Cd exposure on forage growth [1]. Water content of the plants can be affected by climatic conditions and Cd exposure, and tiller and leaf appearance rates are affected by water content. Our aim was to assess the season effect combined to Cd exposure on water content, tiller and leaf appearance rates and biomass production of Brachiaria decumbens Stapf. cv. Basilisk and Panicum maximum Jacq. cv. Massai used for Cd phytoextraction. Both grasses were grown in two soil conditions [pots containing $3 \mathrm{~kg}$ of Cd-uncontaminated and Cd-contaminated (3.6 mg kg ${ }^{-1}$ soil) Typic Hapludox] and two climatic conditions (summer: $30 \pm 2{ }^{\circ} \mathrm{C}, 16 / 8 \mathrm{~h} \mathrm{light} / \mathrm{dark}, 220 \mu \mathrm{mol}$ photons $\mathrm{m}^{-2} \mathrm{~s}^{-1}$, and $75 \pm 5 \%$ relative humidity; and winter: $22 \pm 2{ }^{\circ} \mathrm{C}, 14 / 10$ $\mathrm{h}$ light/dark, $220 \mu \mathrm{mol}$ photons $\mathrm{m}^{-2} \mathrm{~s}^{-1}$, and $55 \pm 5 \%$ relative humidity) during 64 days. After plant harvest, the water content was calculated as the average percent difference between fresh mass and oven dried mass divided by the fresh mass. The number of tillers and leaves of the plants were measured every three days for further calculations. The tiller appearance rate was obtained by dividing the number of tillers that emerged every three days by the total number of existing tillers in the previous count, and the leaf appearance rate was calculated by dividing the number of emerged leaves per tiller by the duration of the evaluation [2]. The water content in the leaf blades, stems + sheaths and roots of the grasses was not changed by the season or $\mathrm{Cd}$ exposure. Otherwise, the water content of $B$. decumbens was 11,9 and $6 \%$ higher than $P$. maximum in the leaf blades, stems + sheaths and roots, respectively. There was no effect of the season and Cd exposure on tiller appearance rate of the forage grasses, but $P$. maximum presented tiller appearance rate $63 \%$ higher than $B$. decumbens. The higher leaf appearance rate (0.056 leave/tiller/day) was observed in $B$. decumbens grown in summer condition and Cd absence. In general, the leaf and root mass productions of $P$. maximum were higher than $B$. decumbens, but the stems + sheaths mass production was not changed by the treatments. The leaf and root mass productions of the forage grasses exposed to $\mathrm{Cd}$ and grown in the winter was a little bit lower as compared to plants grown under $\mathrm{Cd}$ absence and summer condition. There was no clear relationship between water content, tiller and leaf appearance rates and biomass production, which suggests that these plants presents efficient mechanisms to control water content since the biomass production decreased in adversity conditions.

Financial support: São Paulo Research Foundation (FAPESP, Grants 2017/11299-8 and 2018/07190-3).

\section{References}

[1] FHS Rabêlo, L Borgo, J Lavres, "The use of forage grasses for the phytoremediation of heavy metals: plant tolerance mechanisms, classifications, and new prospects," in Phytoremediation: Methods, Management and Assessment, V Matichenkov, Ed. New York: Nova Science Publishers, 2018, pp. 59-103.

[2] MMP Benincasa, Analysis of plant growth: basic notions. $2^{\text {nd }}$ ed. Jaboticabal, SP: FUNEP, 2003. (In Portuguese) 